\title{
Luxury Consumption: Literature Review
}

\author{
Hümeyra Aslım Bilge
}

Ege University, Turkey

\section{INTRODUCTION}

According to the traditional view on the consumer behavior, consumers act rationally choosing the goods that provide the greatest value with the least cost during the buying process. However, the studies on this subject suggest that consumers do not always act rationally and they may sometimes get fully emotional focusing on the feelings like pleasure, happiness, etc., they get through the buying behavior (Altunışı 2007: 111-131). People consume to obtain nice, quality, interesting and luxury goods, and they acquire some rational and hedonic values because of the consumption activity.

Today, the demand for luxury goods is increasing gradually since the individuals can acquire more revenue and enjoy more consumption opportunities thanks to the conditions of the modern era (HusicandCicic 2009: 231). In recent years, the concept of luxury has expanded from materialism to time and passion, and become eventually more available. As consumers satisfy their feelings of pleasure and gratification through the luxury goods, the available luxury products will also continue to enhance its charm for consumers (Yeoman 2011: 50).

Today, the rich have no more a monopoly on the luxury goods. One of the most important factors leading to the actual growth of the luxury market is the introduction of luxury goods to the middle and upper-middle class (Savitha and Sathyanarayan 2014: 86). The figures from the luxury consumption markets in Turkey and the whole world suggest an upward trend, an increase in the share of the upper-middle class in luxury consumption, and some changes on the buying behaviors of the luxury consumers.

According to the Bain \& Company report titled "Luxury Goods Worldwide Market Study Spring 2013", there have been some changes on the customers' preferences for the luxury goods. Consumers prefer the luxury goods with superior quality, craftsmanship and without a logo (www.tribeca.com.tr). It is remarkable to find 
that people do not prefer the brand to appear on the goods they buy. People seem to prefer design, aesthetics and quality to brand.

According to the Bain \& Company report "Global Luxury Goods Worldwide Market Study Spring 2014", the growth rate of the luxury goods market will be 4 $6 \%$ in 2014. There are striking differences across the regions in the global luxury goods market. The luxury markets in Turkey, China and Japan are expected to rise, whereas the Russian market is expected fall. China is the current leader in the global luxury market. The categories expected to get the highest share are accessories and menswear and the demand for luxury goods is increasing rapidly in menswear (haberler.com, 2014).

In "Consumer 2050" report issued by HSBC, it is anticipated that the expenses on luxury goods will grow in the developing economies thanks to the increase in spending power of the middle class. Technology, tourism, entertainment, food and cultural activities are among the industries expected to get the highest share from the luxury consumption (Milliyet, 2013). Since this report includes some longerterm predictions than the Bain \& Company report, there are different anticipations for the industries expected to see an increase in the luxury consumption. The activities including vacation, sightseeing, eating, hedonism, etc. are expected to be associated with luxury in the future.

According to the report "The Changing Dynamics of Luxury Consumption" of The Boston Consulting Group, the total expenses on luxury goods worldwide have reached to 1.8 trillion dollars in 2014. Out of this 1.8 trillion-dollar luxury expenses, the hedonic experiences such as vacation, food, art, etc. get the biggest slice with 1 trillion dollars. Runner-up is the category of luxury cars with 440 billion dollars. Finally, the personal expenses on goods like jewelry, bags, watches and clothing gets the third biggest slice with 390 billion dollars. It is expected that the luxury consumption will grow 7 percent in the future.

Turkey is one of the most important countries in the luxury goods market. In addition, Istanbul gets the biggest share from the luxury consumption in Turkey and it is the $10^{\text {th }}$ fastest growing city worldwide in luxury consumption. The growth in luxury consumption in Turkey is attributed to the growth of the high-income and middle-income groups (EconomyAgenda, 2014). 


\section{THE DEFINITION OF LUXURY}

The consumption goods are often split into three basic classes as luxury goods, inferior goods, and needs. The needs consist of the goods that get the biggest share from the expenses of people with lower income such as food, accommodation, etc. As the income level of people gets higher, they consume more for their vital needs; however, the amount they reserve for these needs gets lower. The inferior goods are the products that are consumed less as the income levels get higher. For instance, people with a higher income may tend to lower the consumption of goods like bread and butter. They may prefer some healthy and expensive goods like meat and olive oil instead (Songer 2014: 15).

Apart from the monetary value, the luxury products can also be associated with some factors like experience, originality and status when addressed from different perspectives (Yeoman 2011: 47). There are different views in literature on the definition and scope of "luxury". The word "luxury" is derived from the Latin word "luxus" and according to its definition in Latin Oxford Dictionary, it refers to "soft or extravagant living, overindulgence" and "sumptuousness, comfort, abundance" (Christodoulides et al. 2008: 397). According to Vigneron and Johnson's definition (1999: 2), the luxury refers to the highest level of prestigious brands that includes various physical and psychological values. From a different perspective, luxury goods are the products $95 \%$ of whom are only available to the $5 \%$ of the population and that have a limited supply (Savitha and Sathyanarayan 2014: 86). In this sense, luxury products trigger social differentiation.

Luxury goods have some features that differentiate them from the needs and inferior goods. A product might be defined as luxury or a need depending on the perceptions of people, culture and the society. Goods can be categorized with a socio-economic segregation instead of a general one that differentiates them as luxury or non-luxury according to their appearance and abstract qualities. The socio-economic segregation considers the economic and development levels of countries. For instance, BMW represents a luxury brand in Turkey and developed European countries; however Opel, which is considered to be a car of a normal level in Turkey, might be perceived as a luxury brand in the underdeveloped or poor countries (Vickers and Renand 2003: 461; Christodoulides et al. 2008: 397).

From the perspective of Economics, goods might be categorized as luxury or a need depending on their elasticity. Goods might be referredtoas luxury when the income elasticity of their demand is higher than that of the other goods. As the household income for these goods increases, the budget spent on luxury rises. The goods are differentiated as luxury or a need depending on the price elasticity of 
their demand. As the prices of the goods defined to be a need rise, the demand for these goods declines relatively. Likewise, as the prices of luxury goods rise, the demand gets lower (Kemp 1998: 592).

When the luxury categorization is based on the usability of the goods, a car might be perceived as a need instead of a luxury product in rural areas with limited transportation options; however it might be considered to be a luxury product for people living in big cities with an extensive transportation network (Vickers and Renand 2003: 461).

The study on luxury by Heine (2012) describes the features of luxury goods as follows.

Table 1: Features of Luxury Products

\begin{tabular}{|c|c|c|c|}
\hline Main Features & Supplier Features & Tangible Features & Intangible Features \\
\hline Price & & Price & \\
\hline \multirow{3}{*}{ Quality } & Supplier's expertise & Material & \\
\cline { 2 - 4 } & $\begin{array}{c}\text { Difficulty of } \\
\text { production }\end{array}$ & Principles of production & \\
\cline { 2 - 4 } & & Labor & \\
\cline { 2 - 4 } & & Product features & \\
\cline { 2 - 4 } & & Product size & \\
\cline { 2 - 4 } & & Service & Aesthetics \\
\hline Aesthetics & & & Uniqueness \\
\hline Rarity & & Rarity & Symbolism \\
\hline Uniqueness & & & \\
\hline Symbolism & & & \\
\hline
\end{tabular}

Source: Heine, Klaus (2012): "The Identity of Luxury Brands", Technical University of Berlin, Department of Marketing, Dissertation, Germany, p. 93.

In literature, the luxury goods are categorized in different ways depending on their unique features. Some studies in literature suggest that goods are categorized into three different methods according to their accessibility in terms of their price and production volume (Siying 2014: 16).

1. Available Luxury Products: This term refers to the situations where the luxury good is available to the majority thanks to its affordable price. 
2. Mid-level Luxury Products: The goods in this class cannot be purchased or accessed by consumers with a limited budget and are only available to certain consumers.

3. Unavailable Luxury Products: This class refers to the goods that can only be afforded by the elite consumers due their special production conditions and high prices.

From a similar perspective, the luxury goods might also be categorized into three different groups as old, new and common. This categorization is described in the following table:

Table 2: Classification of Luxury Products

\begin{tabular}{|c|c|c|c|}
\hline Features & $\begin{array}{c}\text { Old Luxury } \\
\text { Product }\end{array}$ & $\begin{array}{c}\text { New Luxury } \\
\text { Product }\end{array}$ & Common Luxury Product \\
\hline Quality & Hand-made & $\begin{array}{c}\text { Large-scale manual } \\
\text { production }\end{array}$ & $\begin{array}{c}\text { Large-scale factory } \\
\text { production }\end{array}$ \\
\hline Price & High price & Excessive price & Low price \\
\hline Availability & Private & Economic & Normal \\
\hline Attractiveness & Ordinary & Charming & Loyal consumer \\
\hline $\begin{array}{c}\text { Consumer } \\
\text { Segment }\end{array}$ & The elite class & $\begin{array}{c}\text { Luxury-oriented } \\
\text { consumer }\end{array}$ \\
\hline
\end{tabular}

Source: Siying, You (2014): "Marketing Strategy of Chinese Domestic Luxury Brand- Case Company: Kweichow Moutai”, Business Economics and Tourism, VAASA University of Applied Sciences, p.16.

1. Old Luxury Product: The old luxury products with high prices are only consumed by a small group of customers referred to as "elite" thanks to their specific features. This category shares a similarity with the unavailable category of the previous categorization.

2. New Luxury Product: The new luxury products have more engaging and sensual features than the old and common goods, and they are consumed by customers with a high tendency towards luxury consumption. 
3. Common Luxury Product: Common luxury products have functional features like quality and price instead of sensual features, and they are consumed more commonly than the goods in other categories.

Vickers and Renand (2003) adopt a similar approach with the categorizations described above. They state that the categorization of luxury goods shall be based on the socio-economic assessments regarding the goods rather than their specific features. Furthermore, the authors perform a socio-economic categorization that depends on the accessibility of luxury goods. This categorization referred to as luxury product hierarchy is shown below.

Figure 1: Hierarchy of Luxury Products

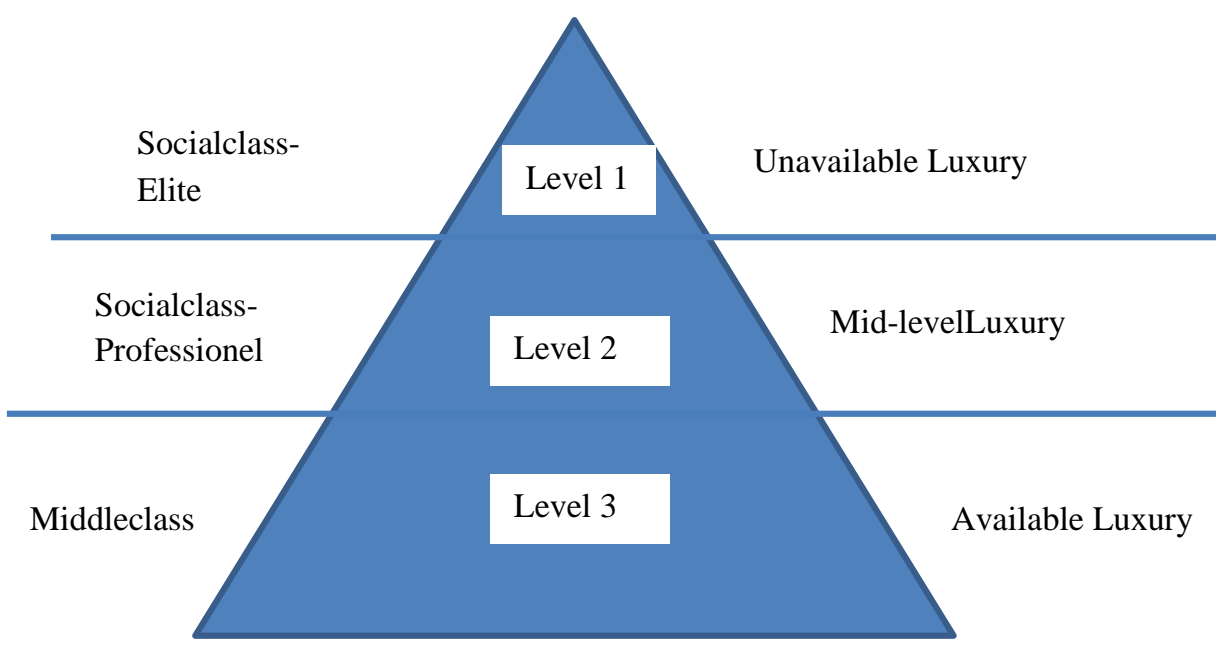

Source: Vickers, Jonathan S; Renand, Franck (2003): "The Marketing of Luxury Goods: An Exploratory Study - Three Conceptual Dimensions", The Marketing Review, Vol. 3, p. 462.

The available luxury level that is at the top of the hierarchy pyramid includes very expensive goods that can only be bought by the elite class and that provide distinctive social prestige to their consumers. The mid-level luxury is a level that is available to the professional class. The available luxury level, on the other hand, is a level that is available to the middle class aiming to climb the social ladder with their buying behaviors.

From a different approach, the luxury goods can be differentiated with three categories based on the brand awareness and price level (Siying 2014: 15): 
1. Low Brand Awareness: This category includes the luxury goods with low brand awareness. The goods in this category are not expensive.

2. High Brand Awareness and High Price: Includes inimitable goods with a high brand awareness and high price. This group has the most expensive and renowned products desired most by the consumers.

3. High Brand Awareness and Affordable Price: The goods with a high brand awareness and affordable price are more popular among consumers as they are more available than the others. Although consumers seek to buy the most expensive and most renowned luxury goods, they may prefer the goods in this category when they have a limited budget.

\section{PERCEPTIONS AND ATTITUDES TOWARDS LUXURY}

The attitudes of consumers towards luxury and the feelings and perceptions of consumers on it are among the factors shaping the concept of luxury. The buying behaviors, loyalty to luxury brands and brand satisfaction of consumers are heavily influenced by how consumers see luxury, which goods they consider luxury, their relationship with luxury and their perceptions on luxury. In this sense, it is very important to assess the perceptions and attitudes of consumers towards luxury brands when deciding on the design, identity, communication, marketing and sales strategies of the luxury brands.

There are various studies on this subject in literature. According to the results of a study on the luxury perceptions of consumers, the personal consumer perceptions towards luxury are as follows. These perceptions are also associated with five basic values that differentiate luxury and non-luxury brands (Vigneron and Johnson 1999: 4-8;Engand Bogaert 2010: 58; Ghanei 2013: 24-25).

1. Perceived conspicuousness: This perception is related to the effect of the reference groups in the luxury consumption process. The conspicuous luxury products that are highly distinctive help their owners to be recognized and to acquire an identity in the reference group. In this sense, the luxury goods serve as a symbol of social status. When people utilize the luxury brands used by celebrities, they benefit from the conspicuousness of these goods to improve their social status.

2. Perceived uniqueness: When a product is manufactured in limited numbers, the demand for it gets higher. Consumers may try to own unique products others cannot have to improve their personal and social identities. When luxury products 
are produced handmade in limited numbers with an original design and high price, their uniqueness is strengthened further.

3. Perceived quality: When compared to the non-luxury brands, the luxury brands provide high quality and accordingly high level of customer satisfaction. Before consumers experience the consumption of a luxury product, they might think that the given product has superior features and performance than the non-luxury products. It is required to keep the product quality consistent in order to create a positive image for the luxury brand.

4. Perceived hedonism: Consumers acquire some emotional values such as pleasure and happiness through the experience of luxury consumption. The luxury products can be categorized as hedonic as they primarily provide emotional experience and values of aesthetics, pleasure and fun.

5. Perceived social value/ego: Consumers consume the luxury goods in order to associate themselves with the symbols inherent in the luxury brands and differentiate themselves from the others. When they own some luxury brands, people expect to be associated with certain prestigious groups, improve their acceptance into such groups, and break off their relations with the non-prestigious reference groups.

Dubois, Laurent and Czellar (2001) performed a comprehensive study on the perception of consumers on luxury consumption in twenty countries and found out the following six features of luxury (Siying 2014: 13-15).

1. Outstanding quality: Quality is one of the most basic features of the luxury goods. Although it is an essential feature of luxury, it must be supported with other features. In addition to the quality, the luxury goods should also provide a perfect service. For example, when a luxury white goods brand that provides quality products does not offer satisfactory after-sales services, the positive perception of customers towards the brand might be damaged.

2. Excessive price: Luxury goods are generally sold at very high prices due to their design, aesthetics and quality. Although the price often represents the quality, this might change depending on the product (Ghanei 2013: 22). On the other hand, an expensive product might be directly perceived to have high quality.

3. A personal story from the past: Luxury goods might have a story thanks to the emotional bond consumers create. When buying these goods, consumers may think that they are also buying the story (Ghanei 2013: 22). They may not hesitate to pay higher prices for these goods as they are much more than products satisfying a need and represent an emotional meaning for them. Luxury goods can tell their stories 
with the marketing and communication activities and they may establish an emotional bond.

4. Rarity and uniqueness: The luxury goods are perceived to be unique since they are not available to everyone. The expensive luxury goods can only be purchased by a certain group of consumers. The value of uniqueness stems from the design, aesthetics, production, and price of the luxury goods.

5. Aesthetics and beauty: The luxury goods have some features related to the aesthetics and beauty. They may trigger emotions like pleasure, gratification and happiness for their owners thanks to these features.

6. Uselessness: The luxury goods are not among those products, which are vital for people to lead their daily lives. This feature is the main factor differentiating luxury goods from the needs. The luxury goods do not aim to provide any rational and functional benefit by fulfilling a function; they rather help people realize their dreams by providing emotional and hedonic benefits.

Consumers have both positive and negative attitudes towards luxury. The authors state that specific features help differentiating the luxury goods from the nonluxury ones. These features are functionality, experimentality and symbolism (Vickers andRenand 2003: 472-474).

The study by De Barnier et al (2006: 8-17) on consumers' perception of luxury in the United Kingdom, France and Russia indicates that the perception of luxury consists of four features for people living in these countries. These features are high quality, high price, and aesthetics and personal story regarding the product/brand. The basic motivation of consumers regarding luxury is to gain some hedonic values like pleasure. In addition to the common perceptions on luxury in these countries, there are also different ones. The British place importance on functionality and luxury atmosphere, the French give weight to passion and charm, and the Russian only care for functionality. The difference in perceptions in these countries may stem from the cultural, social and economic differences.

The perception on luxury is closely related to some psychological factors such as success, status and motivation of people to impress others (Wiedmann et al. 2009: 627). According to the findings of Husic and Cicic's (2009) study, consumers from all social statuses perceive luxury as a status symbol. Regarding the income levels, the highest income group consists of the individuals expending most on the luxury consumption. The rich consumers afford to buy the luxury goods and use these goods in every aspect of their lives. The consumers with less income spend less on the luxury consumption with some motivations like enjoying the product or gaining acceptance by the rich (Husic and Cicic 2009: 242). 
The consumers vary in their attitudes towards luxury. A study by Dubois et al. (2005: 120-125) splits consumers into different groups based on their luxury attitudes.

1. Elitist attitude: The consumers with an elitist attitude believe that only certain people can access luxury. They think that a certain level of education is required to understand and fully enjoy luxury, and that luxury makes sense only to the people in this level. Therefore, luxury should be available only to the intellectual and wealthy people with a certain level of education. Luxury may lose in value when it becomes available to everyone. The luxury goods are extremely expensive and they should not be produced in mass and sold in publicly available stores.

2. Democratic attitude: Unlike consumers with an elitist attitude, consumers with a democratic attitude believe that luxury should be available to everyone. There is no need for a certain level of education in order to assess and gain luxury. The luxury goods do not have to be extremely expensive and they should be produced in mass to make them available to everyone.

3. Distant attitude: For those consumers with a distant attitude, luxury is a concept they do not feel related to. These consumers have a negative attitude towards luxury and consider it unnecessary, extremely expensive, over-embellished and old-fashioned. They usually do not consume any luxury goods and believe that a good imitation can be better than the original. Moreover, these consumers find the people that prefer luxury snob.

There are two underlying reasons for the consumers with a distant attitude to be indifferent to luxury. The first reason is that the consumers consider luxury useless, old-fashioned, extremely expensive, and embellished and that they do not want to own and benefit from the luxury goods. The other reason stems from the personal inadaptability of people to luxury. People may feel anxious and regret for spending too much money on some goods that do not represent them when they perform luxury consumption (Dubois and Laurent 1994: 277).

When reviewing the motivations directing individuals to the luxury consumption, it is common to come across a categorization for the consumption motivations in literature. The motivations for the luxury consumption can be split into two different headings: functional motivations and hedonic motivations (Heine 2012: 149).

The functional motivations are associated with the desire to own a high quality, robust and durable product. On the other hand, the social motivations covered by the hedonic motivations are associated with the behaviors of seeking prestige, flaunting and communicating with others. People may tend towards luxury in order to be accepted into different social groups, gain status, create an identity, develop 
self-respect and attract others' attention. They might consume luxury goods with certain motives such as relaxing, feeling good and being happy. In this sense, the motivations for the luxury consumption bear a striking resemblance to the motivations for the hedonic consumption.

The findings of a study on the buying motivations for jewelry indicate that consumers' behaviors are based on different functional and hedonic motivations for buying jewelry. The functional motivations are the product scale including various features such as product quality, the extent of price scale, size and design, and store's unique location and convenient working hours. Hedonic motivations, on the other hand, are communicating with the personnel in the store, being informed of the new trends, role-playing, enjoying shopping and fun (Jasper and Sanguanpiyapan 2010: 158-159).

The individuals are categorized into four different groups according to the categorization based on their preference of ostentatious or unostentatious goods and consumption motivations (Han et al. 2010: 17).

1. Aristocrat class: The wealthy consumers in the aristocrat class are generally less motivated to tend towards luxury consumption in order to gain prestige and communicate with the other elites. The consumers in this class do not feel obliged to prove themselves as aristocrats as this is already a known fact, and they may tend towards luxury consumption to satisfy their own will.

2. Parvenu class: The consumers in parvenu class tend towards luxury consumption with the motivations of communicating with the aristocrat class, differentiating themselves from the classes other than the aristocrats and gaining status. They act with external consumption motivations rather than internal ones. They have the financial power to access luxury.

3. Poseur class: The consumers in poseur class show themselves to be someone they want to be, but have not become yet, and they may tend towards luxury consumption to gain status. The main difference between this class and the parvenus is that the people in this class cannot afford to own real luxury. Therefore, they may tend towards the imitations of luxury goods and they may spend more on the luxury consumption. This may cause them to feel regret after the luxury consumption.

4. Worker/proletarian class: This is the class where consumers do not aim to gain status, communicate with the wealthy people or differentiate themselves from the others. Luxury makes no sense to the consumers in this class. In addition, these people do not tend towards the luxury consumption, as they do not have the financial power to access luxury. 


\section{LUXURY VALUE}

Consumers acquire a value because of their experience regarding the luxury consumption. The luxury values gained by the consumers can be split into different categories (Wiedmann et al. 2007 4-8; Wiedmann et al. 2009: 628-632).

\section{Financial Luxury Value:}

The price of the luxury goods represents some monetary values like discounts. The price of a product may suggest its price and an expensive product might be perceived as a high quality one. The consumers who categorize expensive products as luxury consider the price of a product as a sign of prestige that will impress others and help gaining status (Ghanei 2013: 24). However, a product does not have to be expensive to be considered as luxury, and it cannot be specified as luxury just because it has a high price. For instance, some products like engagement rings might be perceived as luxury due to their emotional importance rather than their prices.

\section{Functional Luxury Value:}

This value is associated with the basic features of products such as quality, usability, originality and reliability. The basic benefit of a product consists of its tangible features that satisfy the customers' needs. The usability represents the ease of use of a product, and can be defined with its physical, technical and intangible features. The usability of the product depends on the needs of consumers as well as the features of the product. The functional benefit of a product regarding its intended use might be different from the benefit regarding the customers' assessment. In this sense, the benefit of a product might be its stability, robustness and durability as well as its appearance.

\section{Quality Value:}

One of the most important reasons for the consumers to prefer the luxury goods is the quality perception. The special production hand-made luxury goods are particularly better than the non-luxury brands in terms of quality and performance. The consumers perceive a high value for these products since they associate the luxury goods with the brand quality. The consumers tend to buy the luxury goods assessing them with the perception of prestige, and consider high price as a sign of quality (Ghanei 2013: 25).

\section{Uniqueness Value:}


Because of the nature of the uniqueness value, a luxury product should not be publicly attainable. The value perceived by the consumers regarding the rarity and originality of a product increases the demand for this product. The more unique a brand is perceived to be by consumers, the more valuable it becomes. The consumers who regard expensive luxury goods as a sign of prestige do not tend to buy popular brands that are affordable to everyone (Ghanei 2013: 24).

\section{Self-Identity Value:}

The consumers perform luxury consumption in order to create a self-identity. In this sense, when deciding on whether to buy a luxury good, it is expected that the image of the product would correspond to the personal image of the consumer. When people perform luxury consumption to achieve self-realization and intrinsic satisfaction, they might acquire a symbolic value regarding the self-identity value (Özgüngör, 2013: 52).

\section{Hedonic Value:}

In addition to functional benefits, the luxury goods also provide some emotional benefits such as pleasure, fun, excitement and happiness. The consumers buy products with hedonic value with some motivations such as getting happy, feeling positive and relaxing. Wiedmann's study (2009: 644) indicates that "gratification," "pleasure," "self-rewarding", "life enrichment," and "extremeness" are the variables of the hedonic value arising from the luxury consumption.

\section{Prestige Value:}

The luxury goods allow individuals to gain prestige and a social value in the eyes of the reference groups. Therefore, the individuals may desire to utilize a prestigious brand to be accepted into a certain social group(Srinivasan et al. 2014: 101). For example, while a senior manager of a corporate company wears a pair of trousers and a jacket of a luxury brand in the office to promote his professional identity, he/she may prefer to wear casual shorts and sunglasses of a luxury brand when meeting with his/her friends at the weekend to strengthen his social identity outside the office.

\section{Conspicuousness Value:}

According to the related studies in literature, the conspicuousness value of a product affects the sensitivity of other people to the given product (Wiedmann et al. 2007: 8).In this sense, the luxury goods are crucial in determining the position and social status of an individual in the society.

\section{Social Value:}


Social product value reflects some values like prestige and conspicuousness, which affect the consumer trends regarding the luxury consumption considerably (Srinivasan et al. 2014: 99-100). The individual product value, on the other hand, represents the personal opinions of a consumer regarding the luxury consumption, and it is associated with personal factors such as hedonism, self-identity, etc. For instance, the consumers who create a self-image with luxury and branded products might particularly want to show off these products to their friends and try to gain status thanks to luxury consumption.

\section{Materialistic Value:}

Despite the high number of different definitions for materialism in literature, it is generally associated with owning some assets that play crucial roles in people's lives. The individuals with a materialistic view tend to acquire more assets than others and attach more importance to the material gains. People may use their assets to indicate their status and positions, and to contact with the others (Wiedmann et al. 2007: 7). The materialistic consumers who attach great importance to owning luxury goods assess success in terms of what they own and take pleasure in acquiring luxury (Srinivasan et al. 2014: 100).

Figure 2: Luxury Customer Value

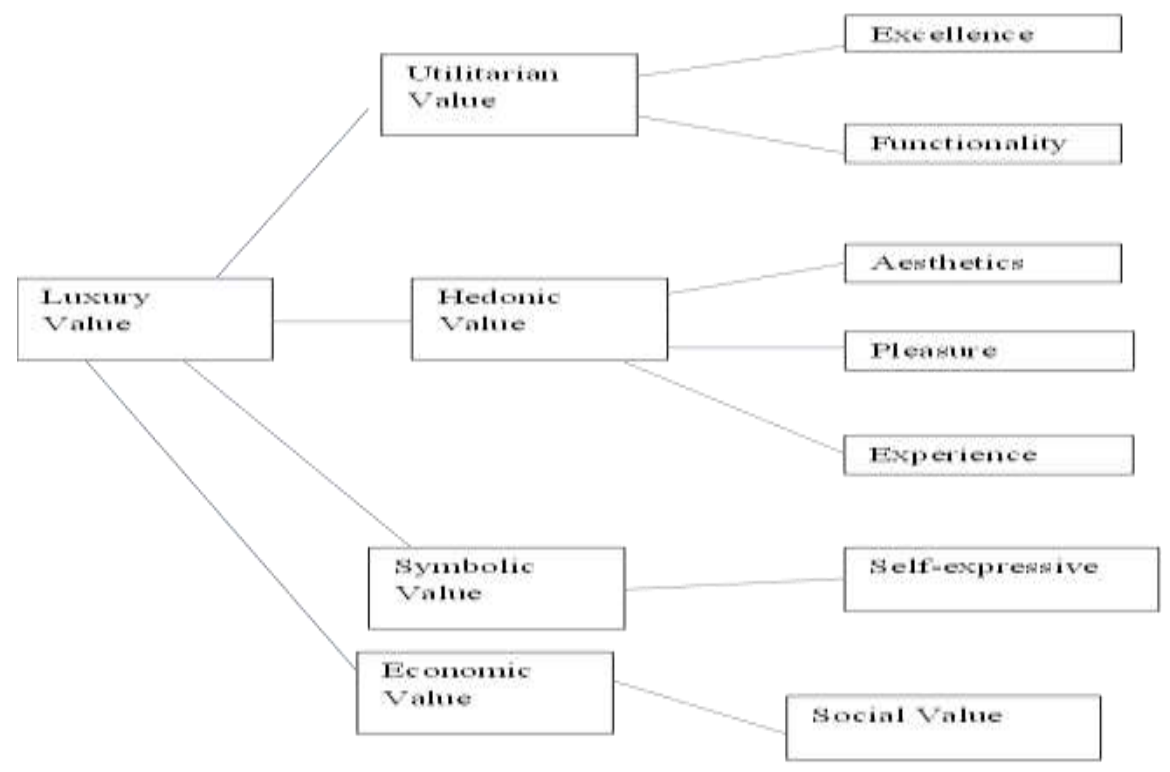

Source: Choo, H. J; Moon H; Kim, H; Yoon N. (2012): “Luxury Customer Value,”Journal of Fashion Marketing and Management, Vol. 16(1), p. 86. 
Choo et al. (2012) created a structure for the luxury value within their studies. The conceptual model they provide is shown in the following figure. They explain the luxury value with utilitarian, hedonic, symbolic and economic values. The utilitarian value includes the excellence and functionality values of luxury goods. The products that are specified to be excellent by the consumers and that can satisfy their functional needs may provide a utilitarian value. The hedonic value consists of three features: aesthetics, pleasure and experience. The products that have an aesthetic design and create a pleasant and amusing customer experience may provide hedonic value. The luxury goods with a symbolic value allow consumers to express themselves and associate the symbolic meaning of the product with their own image. The economic value, on the other hand, can be identified with sociability. The luxury goods that allow people to socialize provide some social benefits. A luxury product can have some or all of these values depending on the purpose of the purchase and the nature of the product.

\section{FACTORS AFFECTING LUXURY CONSUMPTION}

There are various tangible, demographic and social factors affecting the luxury consumption (Kembau and Mekel 2014: 1172-1174; HusicandCicic 2009: 242243). Some of these factors are as follows.

Brand image and quality: People tend towards luxury brand consumption as it is a sign of quality, and they consider a well-known luxury brand to be of good quality.

Therefore, a quality brand with a successful image and a high price might be considered as luxury and purchased by consumers.

Product features: In addition to the emotional features of a product like design and aesthetics, the functional features such as price and quality are among the most important factors that drive consumers to buy the luxury goods. When buying the luxury goods, the assessment of the product features may depend on the gender. According to the findings of a research on fashion consumption, male consumers care for the quality and usability of products, whereas female consumers are interested in aesthetics and design (Kembau and Mekel 2014: 1173).

Atmosphere in the store: The atmosphere of the store where the luxury brands are sold can be important as it may influence the buying behaviors of the consumers. According to the studies on this subject in literature, the store's atmosphere affects the emotional reactions of the individuals during buying process (HusicandCicic 2009: 235-237). The pleasure people get from shopping and their emotional status are affected by some factors such as the store personnel, the interior and exterior of 
the store, the promotions and the after-sales services. People tend to shop in stores where they feel good and get special treatment.

Fashion: Fashion is one of the factors driving luxury consumption. People choose the fashionable products and keep up with the fashion by following the trends.

Role and status: The roles and status people have or want to acquire are among the most important factors affecting the luxury fashion consumption. When people acquire status through the luxury goods, particularly the luxury fashion goods, they may continue the luxury consumption to maintain their position.

The luxury consumption depends on the individuals' need to maintain status. The rich consumers with a little need of status tend to buy unostentatious luxury brands whether others recognize it or not. On the contrary, the rich consumers with a real need of status may buy some ostentatious and conspicuous luxury goods to show off to less wealthy people and demonstrate their difference from them. Consumers who are in need of status, but does not have enough budget to buy real luxury might buy imitations since they are motivated to look rich and acquire a good status.

Social groups: The social groups are among the most important factors affecting the behaviors regarding the luxury consumption. People perform luxury consumption in order to impress others with the luxury goods they own and strengthen their bonds with social groups. This tendency is especially apparent among young consumers. The consumers want to buy some private luxury goods that their friends and the people they aspire do not own. They consider the private and expensive products that are hard to attain as products of more unique value.

Another dimension of the social group factor suggests that people are influenced by the opinions and experiences of others when buying luxury goods. In particular, the young consumers might decide on buying a fashionable product by assessing the opinions of their friends. However, the families have a clear effect on the buying decisions of the young consumers who do not make money and live off their parents' income (Kembau and Mekel 2014: 1177).

Demographic features: Gender plays a significant role in terms of the luxury consumption. Regardless of the gender, people perform luxury consumption due to some factors like quality and trust rather than showing off (Misra 2013: 4). A study on the luxury consumption behaviors of women suggest that women can shine out by leveraging the luxury consumption in the gender rivalry. The women consuming luxury products are perceived as more attractive, mature, charming and intelligent than the women that do not consume them. This finding indicates the importance of preferring luxury goods for women. When compared to men, women has a more positive attitude towards the luxury goods and gain more hedonic value as a result 
of the luxury consumption (Hudders et al. 2014: 573). Consequently, it is important to consider the relationship of women with the luxury consumption when determining the marketing and communication strategies of the luxury brands targeting them.

\section{CONCLUSION}

Today, the luxury consumption is available to the individuals other than the elite and rich class. This boosts the demand for luxury and improves the democratic and positive attitudes of the consumers towards it. A product can be bought by various consumers with different demographic characteristics, expectations and motivations. For example, the consumers expecting a high benefit value put emphasis on the functionality and usability of the luxury goods. The executives of the luxury brands targeting these consumers should prioritize the factors such as quality, functionality and durability in their products. It is getting more important for the executives of the luxury brands to determine a product design and communication strategy that will address the different expectations of the consumers (Ghanei 2013: 44).

The social status and social motives are the distinctive factors that drive people to luxury consumption; however, the quality, reliability and image of the luxury brands also play an important role in this consumption process. Therefore, the executives of the luxury brands are recommended to apply a communication strategy that emphasizes the basic features of the brand rather than the factors like status (Misra 2013: 4). When shaping the buying process, it is important to understand the perceptions and attitudes of the consumers regarding the luxury brands. Consequently, the executives of the luxury brands are recommended to compare the values and perceptions of consumers regarding the luxury brands to the ones of their own brands and revise their marketing strategies and brand positioning in compliance with the expectations of consumers.

The luxury value can be categorized into nine groups: financial value, functional value, uniqueness value, self-identity value, hedonic value, prestige value, conspicuousness value, social value and materialist value. The consumer can evaluate the value of luxury with these nine factors during the buying process. At this point, the executives of the luxury brands shall make sure that the brand has the required features to meet these values.

The increase in the price of the luxury goods results in a rising demand. Conversely, a fall in the price leads to a decrease in the demand. In terms of the 
relationship between the luxury brand awareness and the demand for luxury, the increase in the brand awareness causes a decrease in the demand for the brand (Heine 2012: 105). It is crucial for the luxury brands to take this information into consideration when deciding on the sales, price and strategies of the brand.

People may tend to buy some goods from the same brand and develop a brand loyalty as a result of a positive brand experience. Therefore, it is important for the executives of the luxury brands to create a positive brand experience in the eyes of the consumers. It is also getting even more important for the executives of the luxury brands and the companies to understand the consumers' luxury consumption trends, motivations, perceptions and attitudes towards luxury and the luxury values they are seeking.

Consequently, this study addresses the concept of consumption in terms of the perceptions and attitudes of consumers, and the value of luxury. In this study, the literature has been reviewed for the studies on luxury consumption to make a compilation. In the light of the information acquired, the study makes some recommendations to the executives of the luxury brands. The following studies may choose a luxury brand to do a field study on the attitudes of consumers towards the luxury consumption and the luxury value, and they can do some research regarding the application area of the subject.

\section{References and notes:}

Altunışık, Remzi. (2007). The Differences Between The New Customers Reflecting on The Consumption New Consumer.Editors: Torlak, Ömer;Altunışık, Remzi.Marketing Series 8, Life Periodicals, Istanbul, 111-131.

Choo, H. J; Moon H; Kim, H; Yoon N. (2012). Luxury Customer Value.Journal of Fashion Marketing and Management, 16(1), 86.

Christodoulides, George; Michaelidou, Nina; Li, Hsing Ching. (2008). Measuring Perceived Brand Luxury: An Evaluation of theBLI Scale. Brand Management, 16, 5/6, September, 397.

De Barnier, Virginie; Rodina, Irina; Valette-Florence, Pierre (2006). Which Luxury Perceptions Affect Most Consumer Purchase Behavior? A Cross Cultural Exploratory Study in France, the United Kingdom and Russia.Proceedings des Congrés Paris-Venise des Tendences Marketing, Paris, 8-17.

Dubois, Bernard; Laurent, Gilles (1994).Attitudes towards the Concept of Luxury: An Exploratory Analysis.Asia Pacific Advances in Consumer Research, (1), 277.

Dubois, B; Czellar, S; Laurent, G. (2001).Consumer Rapport to Luxury: Analyzing

Complex and Ambivalent Attitudes.Working Paper 736.HEC School of

Management, France, http://www.hec.fr/hec/fr/professeurs_recherche/ upload/cahiers/CR736.pdf.

Dubois, B; Czellar, S; Laurent, G. (2005). Consumer Segments Based on Attitudes Toward 
Luxury: Empirical Evidence from Twenty Countries.Marketing Letters, (16/2), 120-125.

Eng, Teck-Yong; Bogaert, Julie (2010).Psychological and Cultural Insights into Consumption of Luxury Western Brands in India.Journal of Customer Behaviour, (9/1), 58.

Ghanei, Ali (2013). Luxury Brand Value: What Values Do Customers Create/Co-create Through Their Interaction With Luxury Brands.University of East London, MSC International Business Management, Dissertation, September, 22-44.

Han, Young Jee; Nunes, Joseph C; Drèze, Xavier (2010).Signaling Status with Luxury Goods: The Role of Brand Prominence. Journal of Marketing, (74), July 17.

Heine, Klaus (2012). The Identity of Luxury Brands. Technical University of Berlin, Department of Marketing, Dissertation, Germany, 93-149.

Hudders, Liselot; Backer, Charlotte De; Fisher, Maryanne; Vyncke, Patrick (2014).The Rival Wears Prada: Luxury Consumption as a Female Competition Strategy.Evolutionary Psychology, (12/3), 573, www.epjournal.net.

Husic, Melika; Cicic, Muris (2009).Luxury Consumption Factors. Journal of Fashion Marketing and Management, (13/2), 231-243.

Jasper, Cynthia; Sanguanpiyapan, Thitiporn (2010).Consumer Insights into Luxury Goods: Why They Shop Where They Do in a Jewelry-Shopping Setting.Journal of Retailing and Consumer Services, (17), 158-159.

Kembau, Agung; Mekel, Peggy Adeline (2014).Reference Groups, Family, Roles and Status on Young Consumer Behavior towards Purchase Intentions of Luxury Fashion Brands. Journal EMBA, (2/2), June, 1172-1178.

Kemp, Simon (1998). Perceiving Luxury and Necessity.Journal of Economic Psychology, (19), 592.

Misra C. Gül (2013). Gender, Luxury Affection and Status Consumption in an Emerging Market: The Case of Turkey.Proceedings of World Business and Social Science Research Conference, 24-25 October, Novotel Bangkok on Siam Square, Bangkok, Thailand, 4.

Özgüngör, Bilge (2013). The Relation between Product Design and Consumers' Perception of Value within Luxury Consumer Goods.Master's Thesis, June, Istanbul Technical University Graduate School of Science, Engineering and Technology, 52.

Savitha, S;Sathyanarayan, K. (2014).Taxonomy of Luxury Brand Value.Research Explorer, (III/8), January - June, 86.

Siying, You (2014).Marketing Strategy of Chinese Domestic Luxury Brand- Case Company: Kweichow Moutai. Business Economics and Tourism, VAASA University of Applied Sciences, 13-16.

Songer, Chloe Marie (2014).Branding Luxury: Japan, China, and Vogue.Graduation Paper, April, Duke University, North Carolina, 15.

Srinivasan, R;Srivastava, R.K; Bhanot, Sandeep (2014).A Study of the Antecedents of Purchase Decision of Luxury Brands.Journal of Business and Management, (16/5), May, 99-101.

Vickers, Jonathan S; Renand, Franck (2003).The Marketing of Luxury Goods: An Exploratory Study - Three Conceptual Dimensions. The Marketing Review, (3), 461-474. 
Vigneron, F; Johnson, L. W. (1999). A Review and a Conceptual Framework of PrestigeSeeking Consumer Behavior. Academy of Marketing Science Review, (3/1), 2-8.

Wiedmann, Klaus-Peter; Hennigs, Nadine; Siebels, Astrid (2007).Measuring Consumers' Luxury Value Perception: A Cross-Cultural Framework. Academy of Marketing Science Review, (7), 4-8.

Wiedmann, Klaus-Peter; Hennigs, Nadine; Siebels, Astrid (2009).Value-Based Segmentation of Luxury Consumption Behavior.Psychology\& Marketing, July, (26/7), 627644.

Yeoman, Ian (2011).The Changing Behaviours of Luxury Consumption.Journal of Revenue and Pricing Management, (10), 47-50.

Economy Agenda (2014).Global Luxury Market Has Reached 2 Trillion Dollar.Monthly Economy and Industry Journal, April, http://ekonomiajandasi.net/kuresel-lukstuketim-pazari-2-trilyon-dolara-yaklasti/37627.

Haberler.com (2014). Global Luxury Market Report Is Announced. August, http://www.haberler.com/kuresel-luks-tuketim-urunleri-pazar-raporu-6412612haberi

Milliyet (2013). Consumer 2050 Report Is Announced. February, http://ekonomi.milliyet.com.tr/tuketici-2050-raporu aciklandi/ekonomi/ekonomidetay/02.02.2013/1663766/default.htm.

Tribeca (2013).Generic Luxury Products Are Preferred, July, http://www.tribeca.com.tr/?p=2571. 
SUMMARY

\title{
Luxury Consumption: Literature Review
}

\author{
Hümeyra Aslım Bilge \\ Ege University, Turkey
}

As the demand for luxury increases and luxury goods become more available, the concept of luxury has become an important research area for academic and business communities.

The perceptions of people towards luxury and their expectations from the luxury goods/services might vary greatly. The features like brand image, reliability and quality constitute the positive perceptions regarding luxury. On the other hand, there are also certain features like excessive price and extremeness that can be associated with negative perceptions. The features of luxury can also be used to differentiate luxury goods from nonluxury ones.

The perceptions of people towards luxury can also drive the luxury consumption process. As in all consumption activities, people also acquire some financial, rational, and emotional values because of the luxury consumption.

The purpose of this study is to examine the concept of luxury consumption, address the perceptions and attitudes of people towards luxury, and provide an overview of the luxury consumption. In this study, the literature has been reviewed for the studies on the same subject to make a compilation.

Keywords: Luxury consumption, luxury value, luxury perception. 